\title{
Investigation of Non-covalent Interactions of Metal Complexes with DNA in Cell-free Systems
}

\author{
Andrea Erxleben ${ }^{\star}$
}

\begin{abstract}
Non-covalent interactions of metallo compounds with DNA range from the simple, unspecific electrostatic binding of a positively charged metal complex to the sequence-selective recognition of DNA binding sites due to shape, size, symmetry and hydrogen bonding complementarity of a rationally designed system. Metal complexes that recognize and target specific DNA sequences or particular structures are of considerable interest as therapeutics, diagnostics or structural probes. To gain molecular level insight into DNA-metal complex interactions, binding studies are carried out in cell-free systems using isolated DNA or short oligonucleotides. For this, a powerful toolbox of complementary spectroscopic and biophysical techniques is available. This review focuses on the most frequently applied spectroscopic methods; UV/Vis, CD, LD, fluorescence emission and NMR spectroscopy and is aimed at giving the reader an overview of the qualitative and/or quantitative information that can be obtained. After a short introduction into DNA structures and non-covalent metal complex-DNA interactions, each spectroscopic method will be discussed. In the last section a few selected studies will be described as illustrative examples for the potential of the various spectroscopic methods.
\end{abstract}

Keywords: CD/LD spectroscopy · DNA · Fluorescence emission spectroscopy · NMR spectroscopy · UV/Visspectroscopy

\section{Introduction}

The nucleobases and phosphate groups of DNA provide donor atoms to which metal ions and metal complexes with open coordination sites can bind. Metal ions and complexes can also oxidize DNA nucleobases, in particular guanine, or cleave the sugar phosphate backbone by oxidative, photolytic or hydrolytic mechanisms. ${ }^{[1-3]}$ Irreversible DNA damage such as DNA double strand breaks and oxidation or irreversible covalent bond formation are responsible for metal toxicity and mutagenicity. The probably best known example of covalent metal-DNA binding is the antitumor action of $c i s-\left[\mathrm{PtCl}_{2}\left(\mathrm{NH}_{3}\right)_{2}\right]{ }^{[4]}$ By contrast, rigid, coordinatively saturated and substitutionally inert metal complexes can interact in a reversible, non-covalent manner with DNA. Often multiple contact interactions, i.e. combinations of hydrogen bonding, $\pi-\pi$ stacking and hydrophobic interactions contribute to the binding, giving rise to high binding

${ }^{\star}$ Correspondence: Dr. A. Erxleben School of Chemistry

National University of Ireland Galway

University Road, Galway, Ireland

E-mail: andrea.erxleben@nuigalway.ie affinities and association constants. Thus, non-coordinatively binding agents can inhibit transcription and replication and many display interesting antitumoral, antibacterial and antibiocidal properties. ${ }^{[5]}$ Metal complexes that - due to matching shape and size - interact with specific DNA structures or sequences have tremendous potential as structural probes, fluorescent markers, electrochemical probes or DNA foot-printing agents, in particular given the rich photophysical and electrochemical properties of transition metal compounds. With X-ray crystallography relying on the availability of single crystals and not always reflecting the situation in solution and biological studies not providing molecular level details, spectroscopic investigations of cell-free systems, i.e. isolated DNA or short oligonucleotides can give significant insight. Spectroscopic techniques applied to study non-covalent metal complexDNA interactions range from routine UV/Vis spectroscopy for determining binding constants to sophisticated NMR techniques for elucidating binding sites and conformational and structural changes of the DNA double helix.

\section{DNA Structure}

The DNA double helix of antiparallel polynucleotide strands, held together through hydrogen bonding between the
Watson-Crick base pairs guanine-cytosine and adenine-thymine (Fig. 1), most commonly adopts the right-handed $\mathrm{B}$-form. Other forms include the righthanded A-form and the left-handed Z-form and some less common forms. Besides in chirality, A-, B-, and Z-DNA differ in the distance between adjacent base pairs that are stacked along the helix axis, in the degree of rotation of the helix per base pair and in the sugar pucker. In B-DNA, deoxyribose adopts the $\mathrm{C} 2$ '-endo conformation, while the characteristic zigzag backbone of Z-DNA is a consequence of alternating C3'- and C2'-endo sugar puckers and syn/ anti conformations about the glycosyl bond. The polyanionic sugar phosphate strands form two types of groove, the major groove which in B-DNA is wide and deep (ca. $24 \AA$ in width) and the narrow minor groove (ca. $10 \AA$ in width). ${ }^{[6]}$

Besides the classical Watson-Crick DNA duplex, other nucleic acid forms and higher-order structures are known, such as hairpins (folding of a single strand into a double helix with intramolecular basepairing and an unpaired loop), [7] Holliday junctions with four double-helical $\operatorname{arms}^{[8]}$ and parallel-stranded DNA. [9] Four guanine-rich strands can associate via Hoogsteen hydrogen bonding to a quadruplex containing guanine quartets (Fig. 2). [10] G-quartets are stabilized by monovalent cations such as $\mathrm{K}^{+}$and $\mathrm{Na}^{+}$ that interact with the central $\mathrm{O} 6$ atoms. 
Fig. 1. Sugar phosphate backbone of DNA with the nucleobases adenine $(A)$, guanine $(G)$, cytosine $(\mathrm{C})$ and thymine (T), WatsonCrick base pairs (A-T, G-C) and sugar pucker.
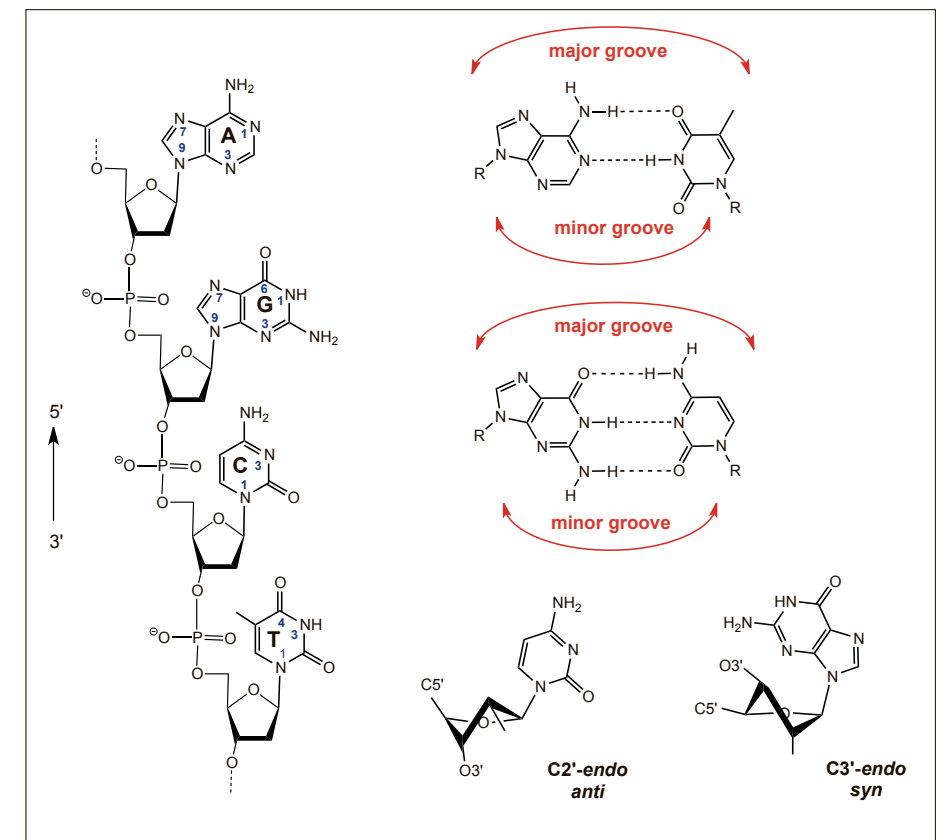

Quadruplex structures are biologically relevant. G-rich sequences that can fold into $\mathrm{G}_{4}$-quadruplexes occur throughout the human genome; they are found in promoter regions of oncogenes, growth control genes, untranslated regions and introns (uncoded regions). ${ }^{[1]}$ In particular, they exist in the telomeres that cap the ends of the chromosomes to protect them from base-pair loss and end-to-end fusion. Telomeric DNA contains doublestranded 5'-d(TTAGGG)-3' repeats with a single-stranded G-rich overhang of up to 200 bases. Human telomeric sequences can adopt three different intramolecular G-quadruplex structures with stacked guanine tetrads. In the presence of $\mathrm{Na}^{+}$, an antiparallel quadruplex forms having one diagonal and two lateral loop regions, ${ }^{[12]}$ while a parallel, propellertype G-quadruplex has been found in the crystalline state in the presence of $\mathrm{K}^{+[13]}$ (Fig. 2). It has been suggested that a hybrid of parallel and antiparallel quadruplex structures exists in solutions containing $\mathrm{K}^{+}$ ions. ${ }^{[14,15]}$

\section{Non-covalent Interactions}

As each nucleotide carries a deprotonated phosphate group, DNA is a polyanion at physiological pH. Manning's polyelectrolyte theory describes the compensation of the negative charges of DNA by a diffuse cloud of highly mobile alkali metal ions surrounding the DNA cylinder. Cationic transition metal complexes such as $\left[\mathrm{Ru}(\mathrm{bpy})_{3}\right]^{2+}$ also interact electrostatically with the negatively charged DNA surface. Other non-covalent DNA binding modes of metal complexes are intercalation, insertion, and groove binding which will be briefly described in the following sections before the various spectroscopic methods are discussed that provide qualitative and/or quantitative information on the metal complex-DNA interactions. While the focus is on the canonical B-DNA helix, the application of spectroscopy in the investigation of noncovalent binding to quadruplex structures is also touched, as quadruplex binders are widely studied as potential anticancer agents.

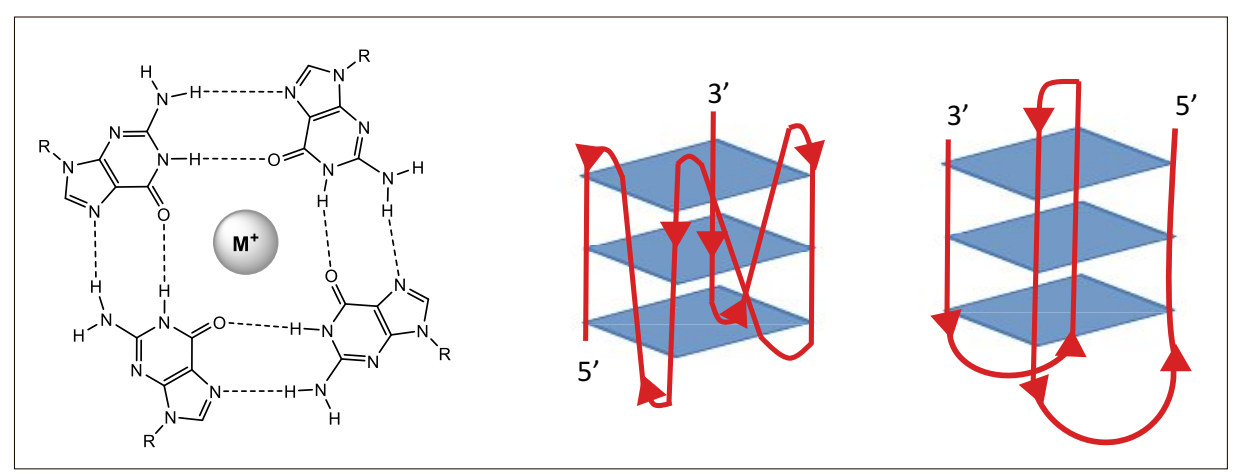

Fig. 2. G-quartets formed by Hoogsteen-H-bonding between four co-planar guanine bases and parallel (left) and antiparallel (right) quadruplexes.

\subsection{Intercalation and Insertion}

A DNA intercalator is a heterocyclic, aromatic, planar molecule that inserts itself between two neighboring, stacked DNA base pairs (Fig. 3). Intercalation results in the widening of the major groove, lengthening, stiffening and unwinding of the double helix but otherwise causes minimal distortion of the DNA structure. ${ }^{[16-18]}$ The degree of unwinding varies. The ethidium cation (Fig. 4), for example, which is widely used in fluorescence displacement assays (vide infra) unwinds DNA by $26^{\circ}$. Binding constants for DNA-intercalator interactions typically range from $10^{5}$ to $10^{11} \mathrm{M}^{-1}$. [19] Two types of intercalation mode can be distinguished, classical and threading intercalation. ${ }^{[20]}$ Classical intercalators simply insert their aromatic entities between base pairs. A threading intercalator contains an intercalating moiety with terminal groups that interact strongly and simultaneously with both grooves (Fig. 3). One of the terminal groups is threaded through the base pair stack. Partial intercalation may occur when full intercalation is hindered by bulky substituents. Metallointercalators comprise square-planar metal complexes with a heterocyclic ligand that intercalates into DNA and octahedral metal complexes with one intercalating polyazaaromatic ligand and one or more ancillary ligands. Certain bis-metallointercalators containing two octahedral polypyridyl entities and a bridging bis-chelating ligand can bind to DNA via threading interaction. ${ }^{[21-23]}$ Fig. 4 shows some typical metallointercalators.

That $\mathrm{Pt}(\mathrm{II})$ complexes such as $[\mathrm{Pt}($ terpy) $\mathrm{X}]^{+},\left[\mathrm{Pt}(\text { phen }) \mathrm{L}_{2}\right]^{2+}$ or $\left[\mathrm{Pt}(\text { phi }) \mathrm{L}_{2}\right]^{2+}$ can interact non-coordinatively with DNA was first shown by Lippard and coworkers in the mid 1971s. ${ }^{[24]}$ Later, mainly pioneered by Barton and coworkers, it was shown that octahedral $\mathrm{Ru}, \mathrm{Rh}$ and Os complexes with polyazaaromatic ligands can recognize specific DNA structures and sites due to matching shape, symmetry and $\mathrm{H}$-bond complementarity. [25-31] The ancillary ligands of octahedral metallointercalators are oriented towards the DNA groove and can confer site and sequence selectivity. More recently, organometallic complexes with $\pi$-bonded arenes have been developed that allow the combination of coordinative (metal) and intercalative (arene) binding modes. ${ }^{[32-38]}$ In contrast to metallointercalators that insert their heterocyclic ligand between intact base pairs, metalloinsertors push the bases of one base pair out of the base pair stack and replace the ejected pair in the stack. ${ }^{[25]}$

\subsection{Groove Binding}

Minor or major groove binders are often crescent-shaped molecules and interact with the hydrogen bond donor and acceptor sites at the floors of the 

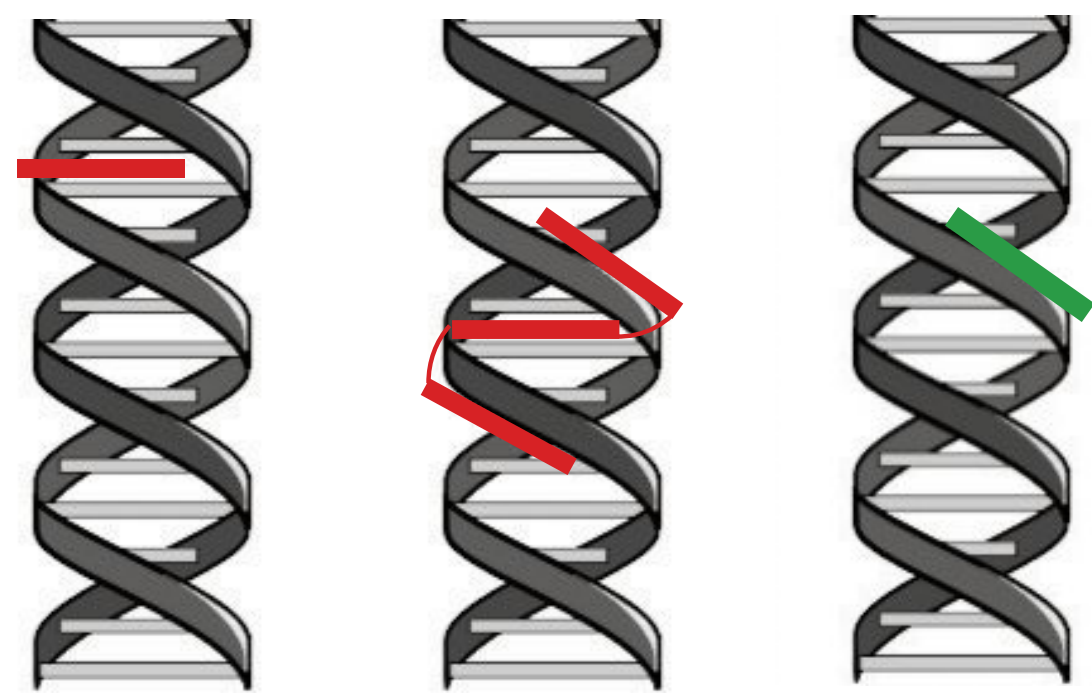

Fig. 3. Intercalation (left), threading intercalation (center) and groove binding (right).

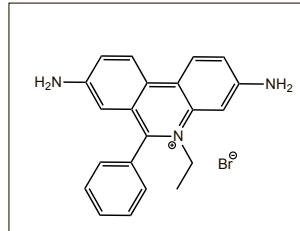

EB

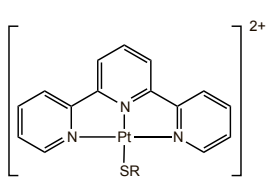

$\left[\mathrm{Pt}(\text { terpy)(RS) }]^{2+}\right.$

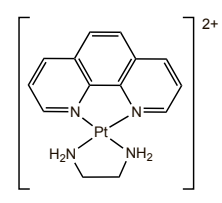

$\left[\mathrm{Pt}(\text { phen)(en) }]^{2+}\right.$

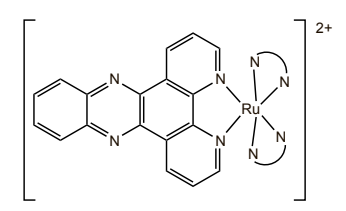

$\left[\mathrm{Ru}(\mathrm{dppz})(\mathrm{L})_{2}\right]^{2+}$
Fig. 4. Molecular structures of ethidium bromide and typical metallointercalators. grooves or nonspecifically through van der Waals contacts or electrostatic attraction. Groove binding results in only minor structural changes of the double helix. ${ }^{39]}$ Usually, groove binders have larger association constants (about $10^{11} \mathrm{M}^{-1}$ ) than intercalators, as there is no cost in free energy for the formation of a binding site. ${ }^{[19]}$ The binding affinity depends on the sequence and the groove, as the position of hydrogen bonding sites and electrostatic potential differ between the major and the minor groove. ${ }^{[39,40]}$ The majority of small molecules bind through the minor groove, preferentially to AT-rich regions. Large, 'round' molecules such as some octahedral tris-chelate complexes or 'cylindrical' metal complexes are known to bind to the major groove (see section 5.2). ${ }^{[41]}$
Due to the peripheral methyl substituents $\left[\mathrm{Ru}(\mathrm{TMP})_{3}\right]^{2+}$ is too large for the minor groove of B-DNA, but preferentially binds to the wider and more shallow minor groove of A-DNA. ${ }^{[42]}$

\section{3 $\mathrm{G}_{4}$-quadruplex Binding via End- stacking}

$\mathrm{G}_{4}$-quadruplexes can be stabilized by flat metal complexes with a large electrondeficient $\pi$-aromatic surface that interact at one or both ends of the quadruplex through $\pi-\pi$ stacking. This is investigated as an anticancer strategy. ${ }^{[43]}$ DNA polymerases cannot replicate the sequences at the end of the chromosomes. Therefore, the telomeres of eukaryotic cells shorten with every cell division and their length is believed to serve as a 'mitotic clock'. When they have
Fig. 5. Groove binding metal complexes.

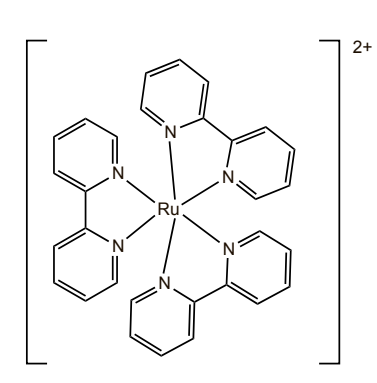

$\left[\mathrm{Ru}(\mathrm{bpy})_{3}\right]^{2+}$

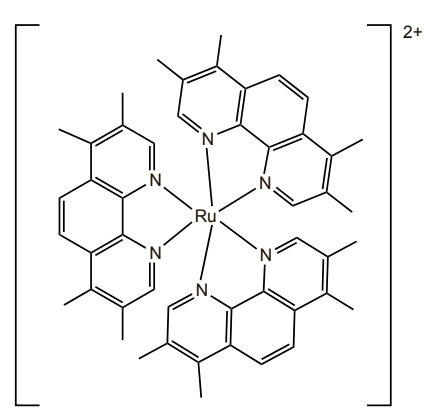

$\left[\mathrm{Ru}(\mathrm{TMP})_{3}\right]^{2+}$ shortened to a critical length, cell death programs are initiated. In $85 \%$ of tumors the enzyme telomerase is overexpressed which maintains the telomere length by adding telomeric repeats to the singlestranded overhang. Folding of the singlestranded telomeric DNA primer into an intramolecular G-quadruplex structure can inhibit telomerase activity. Examples for metal complexes that bind to G-quadruplex structures are shown in Fig. 6. The $\mathrm{Ni}$ complex [Ni(salphen)] that showed significant telomerase inhibition in a PCRbased telomerase activity assay is one of the best quadruplex binders reported to date. ${ }^{[44]}$

\section{Spectroscopic Techniques to Study Non-covalent Interactions}

\subsection{UV/Vis Spectroscopy}

$\mathrm{UV} / \mathrm{Vis}$ spectroscopy is the simplest and most widely used technique to study non-covalent interactions between a metal complex and DNA. It is a convenient method to determine metal complexDNA association constants, but is of limited use for distinguishing binding modes. $\pi$-Stacking with the nucleobases distorts the electron distribution of an intercalator and consequently affects its $\pi-\pi^{*}$ transitions. The energy of the $\pi-\pi^{*}$ transition decreases which causes a red shift (bathochromic effect). When the $\pi^{*}$-orbital of the intercalator couples with the $\pi$-orbitals of the base pairs and when the coupling $\pi^{*}$-orbital is partially filled with electrons, the transition probability decreases resulting in hypochromism of the UV/Vis band of the intercalator. The extent of the hypochromism and red shift is a measure of binding strength. Classical DNA intercalators typically experience a decrease in absorbance of 30 to $40 \%$ on DNA binding. ${ }^{[48-52]}$ The red-shift is usually small ( $\leq 10 \mathrm{~nm})$.

The intrinsic binding constant $K_{b}$ for a metal complex-DNA interaction can be determined by titrating the complex with DNA or DNA with the complex and using the equation

$$
\begin{aligned}
{[D N A] /\left(\varepsilon_{\mathrm{a}}-\varepsilon_{\mathrm{f}}\right)=} & {[\mathrm{DNA}] /\left(\varepsilon_{\mathrm{b}}-\varepsilon_{\mathrm{f}}\right)+1 / K_{\mathrm{b}} } \\
& \left(\varepsilon_{\mathrm{b}}-\varepsilon_{\mathrm{f}}\right)
\end{aligned}
$$

where $\varepsilon_{\mathrm{a}}$ is the apparent extinction coefficient and $\varepsilon_{\mathrm{f}}$ and $\varepsilon_{\mathrm{b}}$ are the extinction coefficients of the free and fully bound complex, respectively.[53] $\varepsilon_{\mathrm{f}}$ is obtained from a calibration curve of the isolated complex following Beer's law, while $\varepsilon_{\mathrm{a}}$ is calculated from the ratio of the observed absorbance $\left(\mathrm{A}_{\mathrm{obs}}\right)$ and the complex concentration. Plotting [DNA] $/\left(\varepsilon_{\mathrm{a}}-\varepsilon_{\mathrm{f}}\right)$ vs. [DNA] gives a straight line. $K_{b}$ is the ratio of the 
Fig. 6. Metal complexes that bind to $\mathrm{G}_{4}$-quadruplexes via end-stacking. ${ }^{[44-47]}$

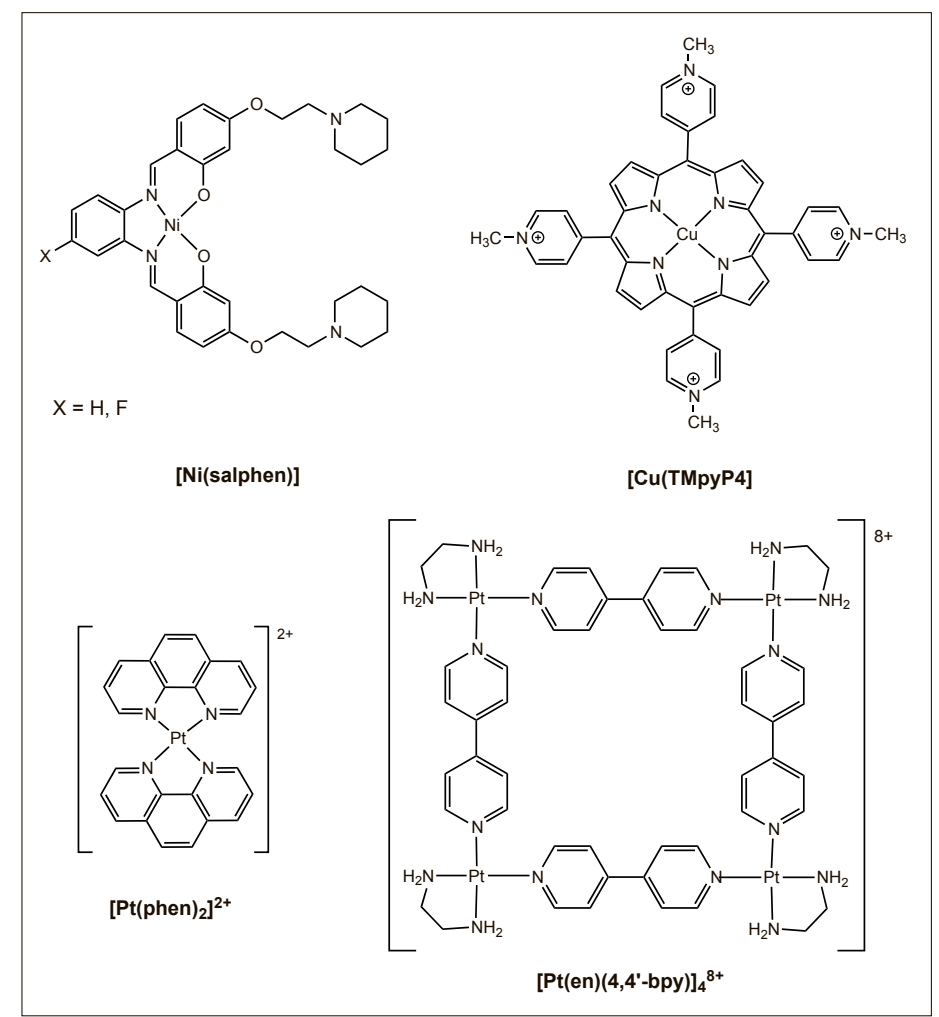

slope and the y-intercept. The binding stoichiometry can be determined by continuous variation analysis. The total molar concentration of the metal complex and DNA is held constant, while their mole fractions are varied. The binding stoichiometry corresponds to the maximum in the plot of the change in absorbance vs. the mole fraction of the metal complex (Job plot). UV/Vis spectroscopy is often applied to compare the binding constants for the interaction of a metal complex with specific DNA sequences or with quadruplex and duplex DNA in order to study the binding specificity.[46,54-58]

The UV/Vis spectrum of DNA features a strong, broad absorption band around $260 \mathrm{~nm}$ due to the $\pi-\pi^{*}$ transition of the four nucleobases $\left(\lambda_{\text {max }}=253-271 \mathrm{~nm}\right)$. Because in double-stranded DNA the nucleobases are stacked inside the double helix, the absorbance is decreased compared to single-stranded DNA. Therefore, the dissociation of the DNA duplex into two single strands on heating (usually referred to as 'melting') can be conveniently monitored by measuring the increase in absorbance at $260 \mathrm{~nm}$ with temperature. The inflection point of the sigmoidal $\mathrm{A}_{260 \mathrm{~nm}} / \mathrm{T}$ curve is defined as the melting temperature $T_{m}$ of DNA. As the fractions of single-stranded and double-stranded DNA and thus $\ln K_{e q}$ can be obtained from the melting curve, $\Delta \mathrm{H}^{\circ}$ and $\Delta \mathrm{S}^{\circ}$ can be determined using $\Delta \mathrm{G}^{\circ}=-\mathrm{RT} \ln K_{e q}$ and $\Delta \mathrm{G}^{\circ}=\Delta \mathrm{H}^{\circ}-\mathrm{T} \Delta \mathrm{S}^{\circ}$. Plotting $\ln K_{e q}$ vs. $1 / \mathrm{T}$ gives a straight line with slope $-\Delta H^{\circ} / \mathrm{R}$ and intercept $\Delta \mathrm{S}^{\circ} / \mathrm{R}$. Intramolecular $\mathrm{G}_{4}$-quadruplex formation and stabilization by metal complexes can also easily be monitored by temperaturedependent UV/Vis spectroscopy. In contrast to duplex formation, folding into a quadruplex structure gives rise to a small hyperchromism at $260 \mathrm{~nm}$ and wavelengths greater than $260 \mathrm{~nm}$ have proved to give more accurate $\mathrm{T}_{\mathrm{m}}, \Delta \mathrm{H}^{\circ}$ and $\Delta \mathrm{S}^{\circ}$ values. ${ }^{[59,60]}$ Mergny et al. have shown that the melting temperature can be accurately determined at concentrations as low as $0.1 \mu \mathrm{M}$, when the absorbance is monitored at $295 \mathrm{~nm}$ where the intensity increases by up to $50-80 \%$ on quadruplex

\subsection{Fluorescence Emission Spec- troscopy}

Fluorescence emission spectroscopy is a sensitive method to study the DNA binding affinity of metal complexes quantitatively, with a wide linear concentration range and high selectivity. Many metallointercalators and groove binders are fluorescent and their fluorescence emission is very sensitive to the environment. A change from a high polarity (aqueous solution) to a low polarity (DNA) environment results in a shift of the excitation and emission band. ${ }^{62]}$ Moreover, on interaction with DNA, an enhancement of fluorescence is generally observed because the metal complex becomes protected from solvent molecules which often act as fluorescence quenchers. Sometimes - for example in the case of $\left[\mathrm{Ru}(\mathrm{phen})_{2}(\mathrm{dppz})\right]^{2+}$ - the increase in fluorescence intensity is so pronounced that the term 'molecular light-switch' has been coined for such systems. ${ }^{[63]}$ Fluorescence formation.[61] quenching by an externally added quencher such as $\left[\mathrm{Fe}(\mathrm{CN})_{6}\right]^{4-}$ has been used to clarify the DNA binding mode. ${ }^{64-67]}$ Groove binders are assumed to be more sensitive to the quencher than intercalators. An intercalating metal complex is less accessible and is additionally protected by the repulsive forces between the negatively charged phosphate groups of DNA and the anionic ferrocyanide. However, Turro and coworkers have recently shown that the fluorescence of strongly but electrostatically bound $\mathrm{Ru}$ complexes can be as efficiently quenched by ferrocyanide as that of related intercalating $\mathrm{Ru}$ complexes. ${ }^{[68]}$ Fluorescence emission spectroscopy is also a useful method for studying the interaction of metal complexes with $\mathrm{G}_{4}$-quadruplex DNA.[56,57,69,70] As in the case of intercalation, binding via external end-stacking can shield the metal complex from aqueous buffer. For example, an up to 293-fold emission enhancement was observed for [Pt(dppz$\mathrm{COOH})(\mathrm{phpy})]^{+}$in the presence of quadruplex DNA. [56] Emission titration can be utilized to determine binding constants and conclusions on binding selectivity have been drawn by comparing the emission enhancement in the presence of quadruplex, duplex and unstructured DNA. [56]

The intercalation of non-fluorescent metal complexes into DNA can be studied by the ethidium bromide (EB) displacement assay. ${ }^{[71]}$ When intercalated into DNA, EB gives a strong emission band at $590 \mathrm{~nm}$. When EB-saturated DNA is titrated with a metallointercalator, the EB emission band decreases, when EB is displaced by the complex.

The linear Stern-Vollmer equation describes the relationship between the relative intensity $\mathrm{I} / \mathrm{I}$ of the emission band and the concentration ratio $\mathrm{Q}$ of the complex and DNA:

\section{$I_{0} / I=1+K_{q}[\mathrm{Q}]$}

where $I_{\mathrm{o}}$ and $I$ are the fluorescence intensities in the absence and in the presence of the metal complex and $K_{q}$ is the quenching constant. The apparent binding constant $K_{a p p}$ can be calculated from the concentration of the metal complex that reduces the EB fluorescence by $50 \%$ and the binding constant for $\mathrm{EB}\left(K_{E B}\right)^{[72]}$ using the equation:

\section{$K_{E B}[\mathrm{~EB}]=K_{a p p}\left[\right.$ metal complex $\left.{ }_{50 \%}\right]$.}

McCann, Kellett and coworkers developed a competitive displacement assay to obtain information on the binding mode of $\mathrm{Cu}$ and $\mathrm{Ag}$ phenanthroline 
complexes using poly[d(A-T) $\left.)_{2}\right]$ and poly $\left[\mathrm{d}(\mathrm{G}-\mathrm{C})_{2}\right]_{\text {. }}{ }^{[73]}$ Poly[d(A-T) $\left.)_{2}\right]$ sequences have a narrower and deeper minor groove than general B-DNA sequences which contributes to the preferential binding of minor groove binders while poly $\left[\mathrm{d}(\mathrm{G}-\mathrm{C})_{2}\right]$ sequences adopt a lefthanded Z-DNA conformation with 12 base pairs per helical turn well suited to accommodate intercalative binding. The assay utilizes unsaturated EB/ polynucleotide and Hoechst 33258/polynucleotide combinations. Complexes that bind to the minor groove have a higher quenching affinity for minor-groove, surface-bound Hoechst/poly[d(A-T) $)_{2}$, while intercalators are more effective in quenching $\mathrm{EB} /$ poly $\left[\mathrm{d}(\mathrm{G}-\mathrm{C})_{2}\right]$, either by direct displacement or by inducing a conformational change that leads to the ejection of the dye.

Displacement assays for $\mathrm{G}_{4}$-quadruplex binders are less well established. A protocol based on the loss of the fluorescence of thiazole orange is described in the literature. ${ }^{74]}$ However, this assay is only suitable for quadruplex binders that do not absorb or fluorescence in the same wavelength range as the indicator. Improved assays with other dyes including Hoechst 33258 and TO-PRO-3 have been suggested,[75,76] but are mainly used for qualitative analysis.

Fluorescence methods can also be used to monitor dynamic processes such as the folding of oligonucleotides into quadruplex structures ${ }^{[77]}$ or the threading of a dumbbell-shaped dinuclear metallointercalator through the base-pair stack of a DNA duplex. ${ }^{[78]}$

\subsection{Fluorescence Resonance En- ergy Transfer Spectroscopy}

In fluorescence (or Förster) resonance energy transfer (FRET) spectroscopy a pair of dyes is used, one acting as a donor, the other as an acceptor. On excitation, the donor transfers its energy to the acceptor via an induced-dipole interaction rather than emitting fluorescence. The acceptor dye then emits fluorescence at a higher wavelength. The efficiency of the energy transfer is inversely proportional to the distance between the two dyes. FRET spectroscopy is a popular method to study the formation and stabilization of G-quadruplexes in the presence of metal complexes. ${ }^{444,45,47,58,79-81]}$ When the 3'- and 5'-ends of the DNA sequence are labeled with a donor and an acceptor dye, their proximity/separation can be easily monitored, e.g. in a FRET melting assay. Frequently, a fluorescein moiety is covalently attached to the 5'-end of an oligonucleotide and a tetramethylrhodamine moiety to the 3 '-end. For example, quadruplex stabilization by
$\left[\mathrm{Pt}(\text { phen })_{2}\right]^{2+}$ and $\left[\mathrm{Pt}(\mathrm{bpy})_{2}\right]^{2+}$ was revealed by an increase in $\mathrm{T}_{\mathrm{m}}$ measured using FRET spectroscopy. ${ }^{[47]}$ Sleiman and coworkers used a FRET melting assay to demonstrate that the supramolecular square [ $\mathrm{Pt}(\mathrm{en})\left(4,4^{\prime}-\right.$ bpy) $]_{4}{ }^{8+}$ is a strong quadruplex binder.[45]

Selectivity for quadruplex DNA over duplex DNA can be determined by a competition FRET-melting assay, i.e. by determining the effect of an excess of double-stranded DNA on the change in $T_{m}$.

FRET spectroscopy is a sensitive method down to $10^{-10} \mathrm{M}$ strand concentration. However, the requirement for cost- and time-consuming dual-labeling is a disadvantage. Furthermore, there is the risk that the labeling destabilizes or perturbs the structure or folding of the oligonucleotide, in particular in the case of a short oligonucleotide and a negatively charged fluorescein entity as the donor label. Thus, for monitoring G-quadruplex formation, linker bases may be required between the G-rich oligonucleotide strand and the donor/acceptor as shown by Mergny and Maurizot. ${ }^{[82]}$

\subsection{Circular and Linear Dichroism}

Circular dichroism (CD) measures the difference in the absorption of right and left circularly polarized light. ${ }^{[83]}$ It is a sensitive method for monitoring conformational changes of DNA. ${ }^{[84,85]}$ Transitions in the DNA bases give rise to a CD spectrum in the 200-350 $\mathrm{nm}$ region due to the chiral sugar at N1 or N9 and due to the helical arrangement of the bases. The CD spectrum of B-DNA consists of a negative band centered at $240 \mathrm{~nm}$ (handedness/ helicity) and a positive band at $275 \mathrm{~nm}$ (base stacking). Simple electrostatic or groove binding interactions of complexes with DNA have a marginal effect on the base stacking and helicity bands, while an intercalative interaction enhances the intensities of both bands. ${ }^{[86,87]}$ In the case of achiral or racemic metal complexes the observation of a CD signal in the region of the optical transitions of the metal complex is evidence for DNA binding. Upon titration into DNA, intercalators usually produce negative induced CD signals or very small positive signals. Groove binding is generally associated with a large positive induced CD signal. Because the signal-tonoise ratio is usually low, CD spectroscopy is limited to qualitative information in most cases, while for the quantitative determination of binding constants UV/Vis or fluorescence spectroscopy are generally preferable.

CD spectroscopy is also widely used to distinguish folding patterns of $\mathrm{G}$-quadruplexes, although recent discussions in the literature suggest to treat structure assignments (parallel, antiparallel or mixed) based on CD data alone with caution. ${ }^{[88-90]}$
Antiparallel structures have a characteristic positive band around $290 \mathrm{~nm}$, a negative band around $265 \mathrm{~nm}$ and a small positive band at $246 \mathrm{~nm} .{ }^{\left[{ }^{91,92]}\right.}$ A positive band near $265 \mathrm{~nm}$ and a negative band around $240 \mathrm{~nm}$ is indicative of a parallel $\mathrm{G}_{4}$-quadruplex. Hybrid parallel/antiparallel conformations are characterized by positive maxima at 265 and $295 \mathrm{~nm}$ and a negative band at $235 \mathrm{~nm} \cdot{ }^{[14]}$ Increases in the quadruplex band intensity upon addition of a metal complex are interpreted as stabilization of the folded DNA species. ${ }^{[93,94]}\left[\mathrm{Pt}(\text { phen })_{2}\right]^{2+}$ and $\left[\mathrm{Pt}(\mathrm{bpy})_{2}\right]^{2+}$, for example, increase the positive band at $290 \mathrm{~nm}$ and the negative band at $260 \mathrm{~nm}$, suggesting that they stabilize the antiparallel G-quadruplex conformation. ${ }^{[94]}$ When the DNA or oligonucleotide is titrated with the metal complex and the change in molar ellipticity is plotted vs. the complex: DNA ratio, the binding stoichiometry can be obtained as the ratio at which the curve levels off. Transitions between different quadruplex structures induced by metal complexes have been monitored by CD titration. ${ }^{[47,94,95]}$ Ren et $a l$, for example, showed that $\mathrm{Zn}$ phthalocyanine complexes fold G-rich sequences into parallel G-quadruplex structures and also convert antiparallel G-quadruplexes into the parallel form. ${ }^{[55]} \Delta \mathrm{T}_{\mathrm{m}}$ of quadruplex structures as a measure of metal complex stabilization are obtained from temperature-dependent CD spectra. ${ }^{[58,95]} \mathrm{CD}$ melting experiments are often the method of choice to determine $\Delta \mathrm{H}^{\circ}$ and $\Delta \mathrm{S}^{\circ}$ for $\mathrm{G}_{4}$-quadruplex formation.

Linear dichroism (LD) is based on the difference in absorption of light polarized parallel and perpendicular to an orientation axis and can be used to probe the orientation of molecules. [83]

LD spectra of DNA are measured in a Couette flow cell in which long molecules, such as DNA, can be oriented through viscous drag. ${ }^{[96]}$ The sample is placed between two concentric cylinders. When one or both of the cylinders are rotated, a shear flow is generated causing long and stiff molecules (DNA at least 1000 base pair long) to align in the flow. The incident linearly polarized light is perpendicular to the flow direction and radial to the flow cell. As the base pairs in B-DNA are stacked approximately perpendicular to the helix axis, i.e. to the flow direction, the $\pi-\pi^{*}$ transitions of the bases give a characteristic negative band in the 220-300 $\mathrm{nm}$ region of the LD spectrum of B-DNA. Molecules that are unbound or bound in a random orientation do not induce a LD signal. Molecules that bind in a specific orientation to the DNA will become oriented in the flow, too, and give LD bands in their spectroscopic region reflective of their average orientation relative to the helix axis. Agents that bend 
or coil DNA lead to a decrease of the DNA LD band, while in the case of intercalators that reduce the flexibility of DNA a band increase is observed. From the LD signal the approximate bend angle per bound molecule can be estimated. [41]

The slow arrangement of threading intercalators from an initial groove-bound state to the threaded state has also been monitored by LD experiments. ${ }^{[78.97]}$

\subsection{NMR Spectroscopy}

Standard 300 to $600 \mathrm{MHz}$ NMR spectrometers give good resolution spectra of DNA oligonucleotides of up to 12 base pairs that allow the determination of the interaction mode, binding sites and conformational changes. Studies with longer sequences are possible with high-field instruments (800 to $1000 \mathrm{MHz}$ ) that are nowadays available.

Groove-binding and intercalation are normally fast on the NMR time-scale so that only one set of resonances is observed for free and bound DNA and metal complex with the line width being determined by the exchange kinetics. Binding constants can be obtained by calculating the fraction of bound metal complex $\mathbf{M}_{\text {bound }}$ from the concentration-weighted change in chemical shift upon titration of the metal complex with DNA:

$$
\begin{aligned}
\delta_{\text {obs }}= & \left(1-\mathrm{M}_{\text {bound }}\right) \delta_{\text {free }}+\mathrm{M}_{\text {bound }} \delta_{\text {bound }} \\
\delta_{\text {obs }}= & \text { chemical shift of the metal com- } \\
& \text { plex at a given titration point } \\
\delta_{\text {free }}= & \text { chemical shift of the metal com- } \\
& \text { plex in the absence of DNA } \\
\delta_{\text {bound }}= & \text { chemical shift of the fully bound } \\
& \text { metal complex }
\end{aligned}
$$

Adenine- $\mathrm{H} 2$ and the sugar protons $\mathrm{H} 1$ ', H4', H2" and one H5' lie in the minor groove and selective changes in the chemical shifts of these protons indicate that the metal complex interacts with DNA via this groove. Significant shifts of the purine H8/ H6, cytosine- $\mathrm{NH}_{2}$ and sugar $\mathrm{H}^{\prime}$ and $\mathrm{H} 3$ resonances identify the major groove as the binding site. The imino protons in the Watson-Crick base pairs which can be observed in $\mathrm{H}_{2} \mathrm{O} / \mathrm{D}_{2} \mathrm{O}$ in the $10-14 \mathrm{ppm}$ range are diagnostic of any disruption of the base pairing on metal complex binding. The analysis of the NMR data is generally facilitated when palindromic sequences can be used, as only the signals of one strand appear. In many cases, detailed information on the binding site, sequence-specific interactions and structural changes to DNA have been obtained from two-dimensional NOESY spectra. NOESY spectroscopy detects through-space interactions between atoms that are less than $5 \AA$ apart with the NOE intensity decreasing with $1 / r^{6}$. On in- tercalation the distance between adjacent bases becomes larger resulting in the disappearance of NOEs of the nucleobases at the intercalation site besides the appearance of intermolecular NOEs between the metal complex and DNA sugar protons. Intercalation also causes a pronounced upfield shift of the ${ }^{1} \mathrm{H}$ NMR signals of the metal complex due to the ring current of the adjacent nucleobases. For example shifts of between -0.4 and -1.0 ppm were observed for the protons of the intercalating biphenyl ligand of $\left[\left(\eta^{6}\right.\right.$-biphenyl $\left.) \mathrm{Ru}(\mathrm{en}) \mathrm{Cl}\right]$. $^{[32]}$ Furthermore, the absence or weakening of the correlation peaks of $\mathrm{H} 3{ }^{\prime}-{ }^{31} \mathrm{P}_{n+1}$ and H3 ${ }^{\prime}-{ }^{31} P_{n}$ along with significant chemical shift perturbations of the H1' and $\mathrm{H} 2$ '/H2" sugar resonances at the sites of intercalation steps have been described. [35] Overlapping resonances in the aromatic region can make NMR studies difficult. Barton and coworkers utilized selective deuteration of the intercalating and/or ancillary ligands to simplify the ${ }^{1} \mathrm{H}$ NMR spectra of the reaction of $\Delta-\left[\mathrm{Ru}(\mathrm{phen})_{2} \mathrm{dppz}\right]^{2+}$ with [d(GTCGAC) ], $\cdot{ }^{[98]}$

A characteristic feature of the NOESY spectrum of B-type DNA is the presence of a cross-peak between purine $\mathrm{H} 8 / \mathrm{H} 6$ and $\mathrm{H} 2$ ' of the same nucleotide (distance $c a$. $2 \AA$ ) that is significantly stronger than that between $\mathrm{H} 8 / \mathrm{H} 6$ and the $\mathrm{H} 2$ ' of the flanking 5'-nucleotide (distance $c a$. $4 \AA$ ). This can be used to detect a conformational change from B-type to non-B-type. As in the case of $1 \mathrm{D}$ NMR, the NOE spectrum will show NOEs between exchange-averaged metal complex resonances and a range of oligonucleotide protons, if binding is fast and occurs at multiple binding sites

When bound to DNA, a metal complex will diffuse more slowly due to the increase in hydrodynamic radius and from the change in diffusion coefficient on titration into DNA the binding constant can be determined. Diffusion can be studied by NMR diffusometry which utilizes pulsed gradient spin-echo pulse sequences. The diffusion coefficient is obtained by plotting the attenuation of a metal complex resonance vs. gradient strength. Diffusion experiments can also probe conformational changes of DNA. Bending of DNA decreases the effective hydrodynamic radius resulting in a larger diffusion coefficient, whereas intercalation which lengthens the DNA leads to a smaller diffusion coefficient.

$\mathrm{G}_{4}$-quadruplex formation is usually slow on the NMR time scale and distinct 1D NMR signals can be observed for the folded and unfolded species allowing the monitoring of the melting profile by integrating selected, well-resolved methyl, imino or aromatic proton signals. Che and coworkers, for example, studied a series of $\mathrm{Pt}(\mathrm{II})$ Schiff base complexes as inhibitors of c-myc oncogene expression. ${ }^{69]}[\mathrm{Pt}(\mathrm{bmpp}) \mathrm{Cl}]^{+}$induced the largest shifts in the imino proton signals of $\mathrm{G}_{5} / \mathrm{G}_{14}$ and $\mathrm{G}_{20}$ of the 5'-TGAGGGTGGIGAGGGTGGGGAAGG-3' sequence, identifying the 3'-terminal face of the c-myc G-quadruplex as the binding site (i.e. external end-stacking). However, the imine resonances of the quadruplex can also experience severe peak broadening (even beyond detection) making assignments difficult or impossible, when the exchange between bound and free metal complex occurs at an intermediate rate on the NMR timescale.

\section{Selected Examples for CD, LD, Fluorescence, and NMR Spectroscopic Studies of Non-covalent Metal-complex DNA Interactions}

\subsection{NMR Studies of Binding Sites and of Shape and Symmetry Selectivity}

The following three examples illustratively show the level of detail on intercalative binding NMR spectroscopy can reveal and how it can elucidate the key elements of recognition of enantiomer and shape selection. In the first example the distinct binding preferences of the $\Lambda$ - and $\Delta$-isomer of $\left[\mathrm{Rh}(\mathrm{MGP})_{2}(\mathrm{phi})\right]^{5+}$ (Fig. 7) were studied. The $\Delta$-isomer recognizes the 5'-CATATG-3' sequence, while the $\Delta$-isomer shows specificity for 5'-CATCTG-3'.[28] When the palindromic 10-mer [d(5'-GACATATGTC-3')], was titrated with $\Lambda$ - $\left[\mathrm{Rh}(\mathrm{MGP})_{2}(\mathrm{phi})\right]^{5+}$, the observed upfield shifts of the imino protons, the disappearance of the $\mathrm{T}_{5}-\mathrm{H} 2$ ' and $\mathrm{H} 2 " /$ $\mathrm{A}_{6}-\mathrm{H} 8$ cross-peaks in the NOESY spectrum and the appearance of cross-peaks between phi protons and $\mathrm{T}_{5}-\mathrm{Me}$ and $\mathrm{T}_{5}$ $\mathrm{H} 2{ }^{\prime} / \mathrm{H} 2$ " allowed the identification of the central $\mathrm{T}_{5}-\mathrm{A}_{6}$ base pair step as the intercalation site. The $\mathrm{T}_{5}$-imino proton experienced an upfield shift of $-1.05 \mathrm{ppm}$ due to the large ring current of the inserted intercalator. The binding was slow on the NMR timescale and only one set of new resonances was observed which indicated that the symmetry of the duplex is retained and that only one bound conformation exists. The $\mathrm{G}_{8}$-imino proton was shifted to lower field by $0.27 \mathrm{ppm}$ consistent with the pendant guanidinium arms hydrogen bonding with $\mathrm{N} 7$ of the $3^{\prime}-\mathrm{G}_{8}$ bases on either side of the intercalation site. NOEs between the guanidinium methylene protons and $\mathrm{T}_{5}-\mathrm{Me}$ and $\mathrm{T}_{7}-\mathrm{Me}$ indicated that the metal complex approaches via the major groove. Furthermore, evidence for the unwinding of the binding site was obtained from the NMR spectra. The difference in chemical shift of $\mathrm{H} 2$ ' and $\mathrm{H} 2$ " 
of the central two bases decreased which suggests an $\mathrm{H} 2$ '/2" environment less asymmetric than in native B-DNA. In addition the large downfield shift observed for $\mathrm{A}_{4}-$ $\mathrm{H} 2$ was in line with an unwound binding site, as unwinding would cause $\mathrm{A}_{4}-\mathrm{H} 2$ moving out of the base stack. The coalescence of free and bound DNA signals was monitored by variable-temperature NMR and the exchange rate and free energy of activation were calculated $\left(\mathrm{k}_{\mathrm{ex}}(298 \mathrm{~K})=\right.$ $\left.68 \mathrm{~s}^{-1} ; \Delta \mathrm{G}^{\neq}=2.7 \mathrm{kcal} \mathrm{mol}^{-1}\right)$. Based on the relatively small activation barrier found, the authors concluded that the significant conformational change and unwinding of the duplex is not induced by the binding of the metal complex, but that the metal complex traps the rather flexible binding site sequence in an unwound state. Similar 1D and 2D NMR studies were carried out for the $\Delta$-isomer of $\left[\mathrm{Rh}(\mathrm{MGP}){ }_{2}(\mathrm{phi})\right]^{5+}$. In contrast to $\Lambda$-[Rh(MGP) $($ phi $)]^{5+}$, two sets of resonances were observed revealing two distinct binding modes in slow exchange. The NOESY cross peaks suggested a deep, canted intercalation from the major groove that brings the phi protons in close proximity of the minor groove A-H2 protons. Binding from the major groove was further confirmed by replacing a guanine base with $N^{7}$-deazaguanine that lacks $\mathrm{N} 7$ as a major groove recognition contact. $N^{7}$ deazaguanine substitution also resulted in a loss of specificity, underlining the role of G-N7 as a key element of recognition.

In the second example chiral discrimination and total enantioselectivity in the binding of a dinuclear $\mathrm{Ru}$ complex to a tridecanucleotide containing a single adenine bulge (Fig. 8) was shown by ${ }^{1} \mathrm{H}$ NMR and NOESY spectroscopy. ${ }^{[99]}$ Addition of $\Delta \Delta-\left[\left\{\mathrm{Ru}\left(\mathrm{Me}_{2} \text { bpy }\right)_{2}\right\}_{2}(\mu-\mathrm{bpm})\right]^{4+}$ to [d(CCGAGAATTCCGG)], led to significant chemical shift changes for the base and sugar protons of the $\mathrm{G}_{3} \mathrm{~A}_{4} \mathrm{G}_{5} / \mathrm{C}_{10} \mathrm{C}_{11}$ bulge site and to a broadening of the resonances of the metal complex. Line broadening can be caused by a decrease in the relaxation times due to a reduced rotational mobility and specific binding. Specific interaction at the bulge site was further supported by the observation that intermolecular NOEs only occur with the nucleotides $\mathrm{G}_{3}, \mathrm{~A}_{4}, \mathrm{G}_{5}$, $\mathrm{C}_{10}$ and $\mathrm{C}_{11}$. By contrast, the NOESY spectrum of the $\Lambda \Lambda$-isomer showed weak NOEs to $\mathrm{C}_{1}-$ and $\mathrm{G}_{13}-\mathrm{H} 1$ ' indicating that binding takes place mainly at the terminal regions of the tridecanucleotide. The resonances of $\Lambda \Lambda$ - $\left[\left\{\mathrm{Ru}\left(\mathrm{Me}_{2} \text { bpy }\right)_{2}\right\}_{2}(\mu-\mathrm{bpm})\right]^{4+}$ remained sharp in line with weak, non-specific interactions. The H1' protons that lie deep within the minor groove did not experience any significant shift changes suggesting that the $\Lambda \Lambda$-isomer is only bound at the surface of the duplex. Competitive binding studies by titrating $\Delta \Delta-\left[\left\{\mathrm{Ru}\left(\mathrm{Me}_{2} \mathrm{bpy}\right)_{2}\right\}_{2}(\mu-\right.$ bpm) $]^{4+}$ into a $1: 1$ mixture of oligonucleotide and $\Lambda \Lambda$ - $\left[\left\{\mathrm{Ru}\left(\mathrm{Me}_{2} \text { bpy }\right)_{2}\right\}_{2}(\mu-\mathrm{bpm})\right]^{4+}$ confirmed the selectivity of the $\Delta \Delta$-isomer for the bulge site. The meso-diasteroisomer $\quad \Delta \Lambda-\left[\left\{\mathrm{Ru}\left(\mathrm{Me}_{2} \mathrm{bpy}\right)_{2}\right\}_{2}(\mu-\mathrm{bpm})\right]^{4+}$ undergoes fast exchange allowing the determination of the association constant from the NMR data $\left(4 \times 10^{4} \mathrm{M}^{-1}\right)$. As in the case of the $\Delta \Delta$-isomer, the resonances of the nucleotides near the bulge site shifted. One of ligand protons exhibited a NOE with $\mathrm{G}_{5}-\mathrm{H} 1$ ' that was stronger than in the case of $\Delta \Delta$-[\{Ru(Me ${ }_{2}$ bpy $\left.)_{2}\right\}_{2}(\mu-$ bpm) $]^{4+}$ and along with the observation of an additional relatively strong ligand$\mathrm{CH}_{3} / \mathrm{G}_{3}-\mathrm{H} 1$ ' cross-peak this suggested a deeper binding within the groove. Further analysis of the NMR data led the authors to the conclusion that the $\Delta$-center tightly penetrates from the minor groove, while the $\Lambda$-center is projected out of the groove. Furthermore, NOEs to $\mathrm{A}_{6}-\mathrm{H} 1$ ' and

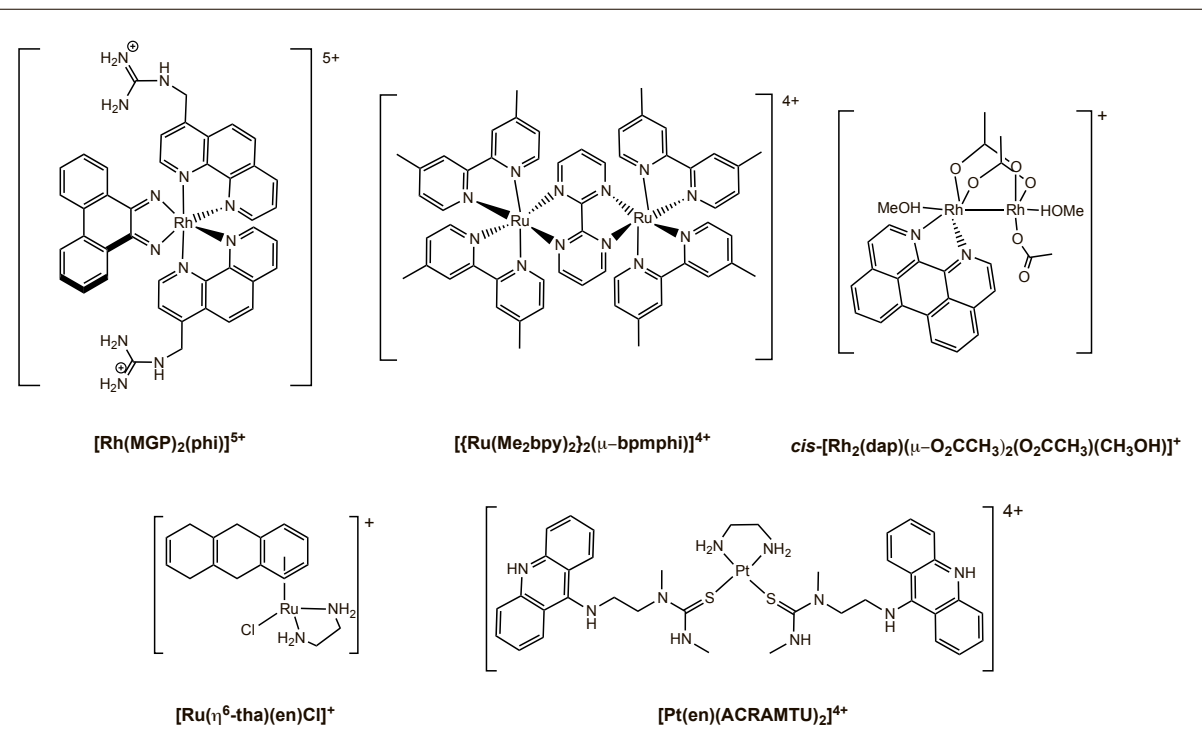

Fig. 7. Structures of the complexes discussed in section 5.1.
$\mathrm{G}_{12}-\mathrm{H} 1^{\prime}$ indicated that the $\Delta \Lambda$-isomer can move up and down the groove. Overall, the greater number of NOEs observed for the meso-diastereoisomer demonstrated that $\Delta \Lambda-\left[\left\{\mathrm{Ru}\left(\mathrm{Me}_{2} \text { bpy }\right)_{2}\right\}_{2}(\mu-\mathrm{bpm})\right]^{4+}$ is less selective than the $\Delta \Delta$-isomer.

Metal complexes that are capable of bifunctional DNA interaction via coordinative and intercalative binding differ from cisplatin in the way they distort the DNA and often have interesting anticancer properties. Several detailed NMR studies are described in the literature that provide insight into binding and intercalation sites and structural distortions of the DNA helix. [32-36] The dinuclear Rh complex $\quad c i s-\left[\mathrm{Rh}_{2}(\mathrm{dap})\left(\mu-\mathrm{O}_{2} \mathrm{CCH}_{3}\right)_{2}\left(\eta^{1}-\right.\right.$ $\left.\left.\mathrm{O}_{2} \mathrm{CCH}_{3}\right)\left(\mathrm{CH}_{3} \mathrm{OH}\right)\right]^{+}$containing two labile cis ligands on one $\mathrm{Rh}$ and an intercalating chelate ligand on the other one was developed by Turro, Dunbar and coworkers. ${ }^{[100]}$ Its reaction with the 12-mer duplex d(CTCTCAACTTCC) $\bullet d(G G A A G-$ TTGAGAG) was investigated by 2D NMR. ${ }^{[34]}$ The insertion of the dap ligand between the $\mathrm{A}_{6}-\mathrm{T}_{19}$ and $\mathrm{A}_{7}-\mathrm{T}_{18}$ base pairs was evidenced by (i) a disturbance of the NOE connections between $\mathrm{A}_{6}$ and $\mathrm{A}_{7}$ and

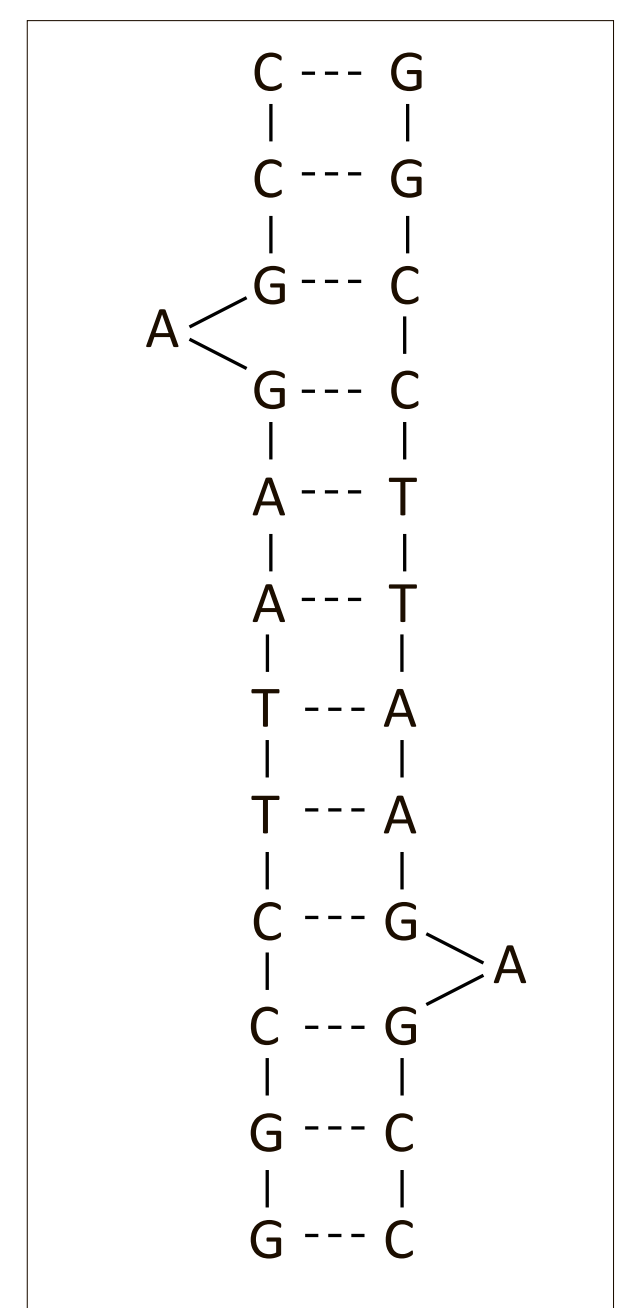

Fig. 8. Tridecanucleotide with adenine bulge. 
between $\mathrm{T}_{18}$ and $\mathrm{T}_{19}$, (ii) the absence of cross-peaks of $\mathrm{H} 2$ and $\mathrm{H} 8$ of $\mathrm{A}_{6}$ and $\mathrm{A}_{7}$ (which are very strong in the unmetallated duplex) and (iii) the appearance of crosspeaks of dap protons with both the $\mathrm{H} 2$ and $\mathrm{H} 8$ protons of $\mathrm{A}_{6}$ and $\mathrm{A}_{7}$. The $\mathrm{A}_{6}-\mathrm{H}_{8}$ resonance underwent a small net downfield shift as a result of the opposing effects of $\mathrm{Rh}$ coordination to $\mathrm{A}_{6}-\mathrm{N} 7$ (induction of a downfield shift) and the ring current of the intercalating dap ligand (induction of an upfield shift).

Another illustrative example where a range of sophisticated 2D NMR methods were applied to study the intercalation of a bifunctional metal complex was reported by Sadler and coworkers. ${ }^{[35]} 2 \mathrm{D}$ $\left[{ }^{1} \mathrm{H},{ }^{1} \mathrm{H}\right]$ TOCSY, 2D $\left[{ }^{1} \mathrm{H},{ }^{31} \mathrm{P}\right] \mathrm{HSQC},{ }^{15} \mathrm{~N}-$ edited $\left[{ }^{1} \mathrm{H},{ }^{1} \mathrm{H}\right]$ NOESY and ${ }^{15} \mathrm{~N}$-decoupled $\left[{ }^{1} \mathrm{H},{ }^{1} \mathrm{H}\right]$ NOESY experiments along with changes in the ${ }^{1} \mathrm{H}$ NMR chemical shifts of the $\mathrm{H} 8$ resonances showed that the organometallic Ru complex $\left[\left(\eta^{6}\right.\right.$-tha $) \mathrm{Ru}(\mathrm{en})$ $\mathrm{Cl}]^{+}$metallates the $[\mathrm{d}(\mathrm{CGGCCG})]_{2}$ duplex selectively at $G_{3}$ and $G_{6}$ while the noncoordinated rings of the tha ligand selectively intercalate between the $\mathrm{G}_{3}-\mathrm{C}_{10} / \mathrm{C}_{4}-\mathrm{G}_{9}$ and $\mathrm{G}_{6}-\mathrm{C}_{7} / \mathrm{C}_{5}-\mathrm{G}_{8}$ base pairs. In the case of the $\mathrm{G}_{3}$-coordinated duplex, weak to intermediate intensity NOEs between tha ring protons and $\mathrm{H}^{\prime}$ or $\mathrm{H} 8$ of $\mathrm{G}_{3}$ or $\mathrm{C}_{4}$ were observed. Furthermore, the protons of the tha ligand showed NOEs of intermediate intensity indicating that the aromatic ligand also interacts at the $\mathrm{G}_{9} \mathrm{C}_{10}$ base pair step, penetrates deeply and is located between the middle of the $\mathrm{G}_{9}$ and $\mathrm{C}_{10}$ bases. Similar effects were seen in the spectra of the $\mathrm{G}_{6}$-coordinated duplex.

The bisintercalative DNA binding mode of the $\mathrm{Pt}(\mathrm{II})$ complex $[\mathrm{Pt}(\mathrm{en})(\mathrm{AC}$ RAMTU) $\left.)_{2}\right]^{4+}$ containing two intercalating acridine moieties is an example where NMR spectroscopy was complemented with fluorescence emission, UV/Vis, and CD spectra to study all aspects of the binding interaction. ${ }^{[101]}$ The EB displacement assay was utilized to compare the binding affinity with that of the analogous mono-intercalator and to evaluate the relative affinities for different sequences; poly $\left[\mathrm{d}(\mathrm{G}-\mathrm{C})_{2}\right]$, calf-thymus DNA, and poly $\left[\mathrm{d}(\mathrm{A}-\mathrm{T})_{2}\right]$. The results showed a threefold higher selectivity of the bisintercalator for AT sequences compared to the mono-intercalator. The UV/Vis melting assay revealed an increase in the thermal stability of the duplex, while the increase in ellipticity and a $7 \mathrm{~nm}$ blue shift of the positive $C D$ band indicated a change in DNA conformation. Differences in the induced circular dichroism in the 300-500 $\mathrm{nm}$ range suggested different alignments with adjacent base pairs in the case of $\left[\mathrm{Pt}(\mathrm{en})(\mathrm{ACRAMTU})_{2}\right]^{4+}$ and free acridine. NOESY spectra showed deep bisintercalation of the acridine entities from the minor groove into the 5'-TA/TA base pair step of [d(GCTATAGC $)]_{2}$ while the Pt linker part resides in the minor groove.

\subsection{Interaction of Supramolecular Complexes with DNA Studied by $C D, L D, N M R$ and Fluorescence Spectroscopy}

While small-molecule DNA binders have been an active field of research for several decades now, more recently there is increasing interest in metallo-supramolecular agents interacting non-covalently with DNA. These compounds are typically highly charged and thus bind with high affinity to polyanionic DNA. LD is often the method of choice to confirm that a supramolecular metal complex binds to DNA in a specific orientation.

Recognizing the analogy of metal-supramolecular helicates to the cylindrical binding units of transcription factors such as $\alpha$-helices or $\mathrm{Zn}$ fingers that insert into the major groove, Hannon and coworkers studied the interaction of dinuclear, triple helical, chiral tris-chelate systems with DNA. ${ }^{[41]}$ Tetracationic $\left[\mathrm{Fe}_{2} \mathrm{~L}_{3}\left[{ }^{4+}\right.\right.$ (Fig. 9) represents a structurally rigid cylinder stabilized through face-edge $\pi-\pi$ interactions. The LD spectrum showed a signal in the metal complex region at $580 \mathrm{~nm}$ indicating non-random binding as well as a decrease of the intensity of the $260 \mathrm{~nm}$ DNA signal. When $\left[\mathrm{Fe}_{2} \mathrm{~L}_{3}\right]^{4+}$ was titrated into the DNA solution, the $580 \mathrm{~nm}$ signal intensity divided by the $\left[\mathrm{Fe}_{2} \mathrm{~L}_{3}\right]^{4+}$ concentration (i.e. per molecule) decreased more slowly than the DNA signal. Complementary CD spectra demonstrated that the B-DNA structure was retained without any significant disruption of the local structure. These spectroscopic data are in line with a shortening of the DNA through bending. The percentage reduction of the $260 \mathrm{~nm}$ LD signal was used as a measure of the bending effect of different cylinders. ${ }^{[102]}$

$\mathrm{CD}$ and LD spectroscopy was also used to obtain information on the DNA binding of the metallo-rectangle shown in Fig. 9. ${ }^{[103]}$ The 200-300 $\mathrm{nm}$ region of the CD spectrum corresponded to B-form DNA, while the reduction of the LD DNA signal indicated bending of the DNA. The ligand region of the LD spectrum featured two negative bands which suggested that the rectangle orients itself so that the ligands are parallel to the DNA bases, possibly with partial intercalation.

Metallo-calixarenes are container molecules that are analogs of the classical organic calixarenes in that the methylene groups and phenol rings are replaced by a metal fragment and a nitrogen heterocycle, respectively. ${ }^{[104]}$ Galindo et al. showed by CD and LD spectroscopy that the Pt-based calixarenes displayed in Fig. 9 reduce the flexibility of DNA and aggregate DNA. ${ }^{[105]}$ As in the case of the metallo-cylinders the induction of CD and LD bands in the metal complex spectral region gave evidence for DNA binding and interaction in a specific, non-random orientation. In contrast to the cylinders the metallo-calixarenes caused very little change in the DNA bands in the 220-300 $\mathrm{nm}$ region of the LD spectrum, consistent with a non-intercalative binding mode.

Competition binding assays with EB, the minor groove binder Hoechst 33258 and the major groove binder $\left[\mathrm{Co}\left(\mathrm{NH}_{3}\right)_{6}\right]^{3+}$ were used to determine the binding constants for the $\mathrm{P}$ and $\mathrm{M}$ enantiomers and differently substituted $\left[\mathrm{Fe}_{2} \mathrm{~L}_{3}\right]^{4+}$ cylinders (Fig. 9) in order to gain more insight into

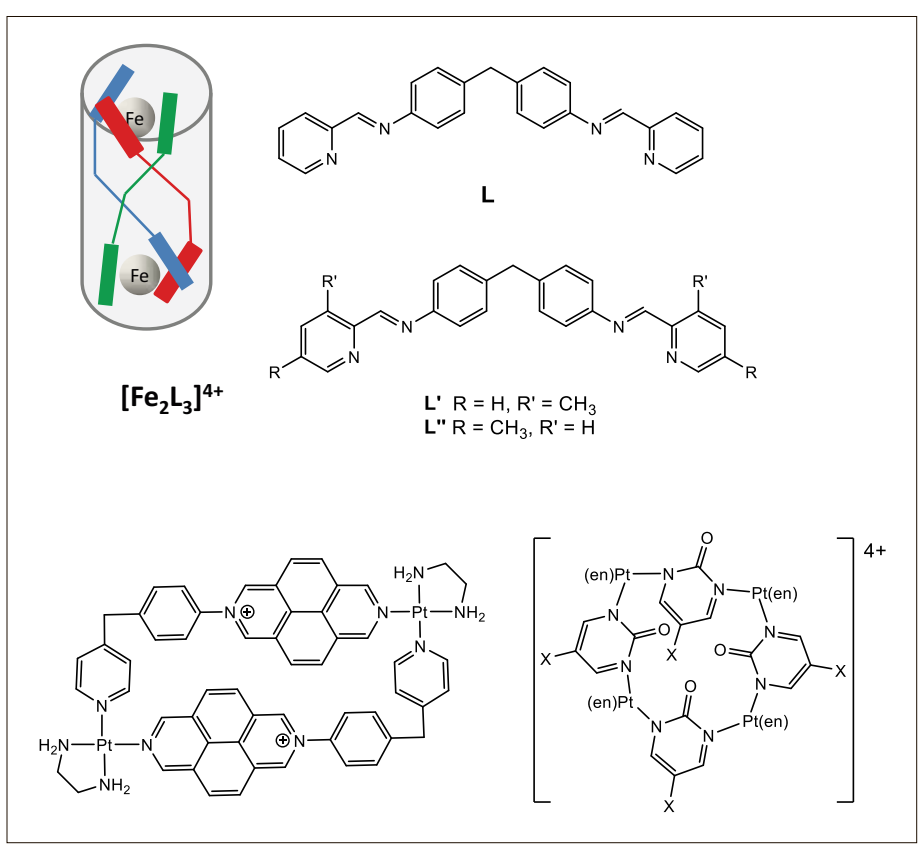

Fig. 9. Metallocylinders, metallorectangle and metallo-calixarenes. 
the effects of the length and width of the helicates on the binding strength and groove selectivity. ${ }^{[102]}$ All helicates were found to have higher binding constants than EB indicating strong binding. The $\mathrm{M}$ isomer of $\left[\mathrm{Fe}_{2} \mathrm{~L}_{3}\right]^{4+}$ bound in the major groove and induced significant coiling. The $\mathrm{P}$ isomer on the other hand displaced both the minor groove binder Hoechst as well as the major groove binder $\left[\mathrm{Co}\left(\mathrm{NH}_{3}\right)_{6}\right]^{3+}$. It was suggested that the less effective DNA bending observed with $\mathrm{P}-\left[\mathrm{Fe}_{2} \mathrm{~L}_{3}\right]^{4+}$ was the result of this isomer binding to both grooves.

1D and 2D NMR spectroscopy was used to show that the $\mathrm{M}$ enantiomer of $\left[\mathrm{Fe}_{2} \mathrm{~L}_{3}\right]^{4+}$ arranges the palindromic 6-mer [d(CGTACG) $]_{2}$ and 12-mer [d(TATGGTACCATA) $]_{2}$ into three-way junctions (Fig. 10). ${ }^{[106]}$ The integrated intensities of the methyl signal of the central $\mathrm{T}$ and the imine signal of $\left[\mathrm{Fe}_{2} \mathrm{~L}_{3}\right]^{4+}$ indicated a 1:3 stoichiometry, consistent with the metallo-helicate located in the center of three double helices forming the junction. Furthermore, the six imine protons of the helicate split into two peaks of equal intensity showing that the two-fold symmetry of the helicate is lifted, while its three-fold symmetry is retained. Strong $\pi$-stacking interactions with the nucleobases was evidenced by pronounced shifts of the phenyl and methylene resonances of the metal complex. NOE intensities and ${ }^{31} \mathrm{P}$ NMR data confirmed that the only structural distortion occurs at the central T-A region involved in the junction.

\subsection{Quadruplex Binding Stud-} ied by Fluorescence, CD and NMR Spectroscopy

The dinuclear $\mathrm{Ru}$ complex $\left[\left\{\mathrm{Ru}(\mathrm{phen})_{2}\right\}_{2} \text { tpphz }\right]^{4+}$ is an interesting example where a combination of emission titration, CD spectroscopy and NMR spectroscopy was applied to investigate enantioselective quadruplex binding.[70] The luminescence enhancement on addition of quadruplex DNA was found to depend on the diastereomer and emission titration showed that the $\Lambda \Lambda$-isomer binds approximately 40 times more strongly than the $\Delta \Delta$-isomer and gives a stronger luminescence. In the case of the $\Lambda \Lambda$-isomer peak broadening and loss of intramolecular NOEs were observed for both ends of the quadruplex, while in the spectrum of the $\Delta \Delta$-isomer severe line broadening occurred mainly for signals from the lateral loop end. It was suggested that in contrast to the $\Delta \Delta$-isomer, $\Lambda \Lambda$ - $\left[\left\{\operatorname{Ru}(\text { phen })_{2}\right\} \text {,tpphz }\right]^{4+}$ stacks onto the tetrad underneath the diagonal loop (Fig. 2) where it is shielded from the solvent.

\section{Concluding Remarks}

UV/Vis, fluorescence, CD, LD and NMR spectroscopies are routinely used to study non-covalent interactions between a metal complex and DNA in cell-free systems. In particular NMR spectroscopy can give detailed insight into the specific binding mode (intercalation, groove-binding, end-stacking to $\mathrm{G}_{4}$-quadruplex structures) and help rationalize sequence- and structure selectivity. To obtain qualitative as well as quantitative information on noncovalent binding interactions, it is usually necessary to apply a combination of different spectroscopic methods. While this review focused on UV/Vis, fluorescence, CD, LD and NMR as the most widely applied spectroscopic techniques, it should be noted that a range of other analytical methods such as viscosimetry, cyclic voltammetry, isothermal titration calorimetry, or competition dialysis and biochemi-

cal assays such as footprinting, PCR stop and topoisomerase inhibition assays also play an important role in the study of DNA binding.

\begin{tabular}{|c|c|}
\hline \multicolumn{2}{|c|}{ Abbreviations } \\
\hline A & adenine \\
\hline ACRAMTU & 1-[2-(acridine-9-ylamino)ethyl] \\
\hline & 1,3-dimethylthiourea \\
\hline bmpp & $\begin{array}{l}\text { 2,6-bis[1-(3-morpholinopropyl)- } \\
1 H \text {-pyrazol-3-yl]pyridine }\end{array}$ \\
\hline bpm & 2,2'-bipyrimidine \\
\hline bpy & 2,2'-bipyridine \\
\hline 4,4'-bpy & 4,4'-bipyridine \\
\hline $\mathrm{C}$ & cytosine \\
\hline $\mathrm{CD}$ & circular dichroism \\
\hline dap & 1,12-diazaperylene \\
\hline dppz & dipyridophenazine \\
\hline dppz-COOH & $\begin{array}{l}\text { 11-carboxydipyrido }\left[3,2-a: 2^{\prime}, 3^{\prime}-c\right] \\
\text { phenazine }\end{array}$ \\
\hline en & ethylenediamine \\
\hline FRET & $\begin{array}{l}\text { fluorescence resonance energy } \\
\text { transfer }\end{array}$ \\
\hline G & guanine \\
\hline HSQC & $\begin{array}{l}\text { heteronuclear single quantum } \\
\text { coherence }\end{array}$ \\
\hline $\mathrm{L}$ & ligand \\
\hline LD & linear dichroism \\
\hline $\mathrm{Me}_{2}$ bpy & 4,4'-dimethyl-2,2'-bipyridine \\
\hline MĞP & $\begin{array}{l}\text { 4-(guanidylmethyl)-1,10-phenan- } \\
\text { throline }\end{array}$ \\
\hline NMR & nuclear magnetic resonance \\
\hline NOE & nuclear Overhauser effect \\
\hline NOESY & $\begin{array}{l}\text { nuclear Overhauser effect spect- } \\
\text { roscopy }\end{array}$ \\
\hline PCR & polymerase chain reaction \\
\hline phen & 1,10-phenanthroline \\
\hline phi & phenanthrenequinone diimine \\
\hline phpy & 2-phenylpyridine \\
\hline $\mathrm{T}$ & thymine \\
\hline terpy & $2,2^{\prime}: 6^{\prime}, 2^{\prime \prime}$-terpyridine \\
\hline tha & tetrahydroanthracene \\
\hline TMP & $3,4,7,8$ tetramethylphenanthroline \\
\hline TMpyP4 & $\begin{array}{l}\text { 5,10,15,20-tetrakis-(1-methyl- } \\
\text { 4-pyridyl)-21H,23H-porphine }\end{array}$ \\
\hline $\begin{array}{l}\text { TOCSY } \\
\text { tpphz }\end{array}$ & $\begin{array}{l}\text { total correlation spectroscopy } \\
\text { tetrapyrido[3,2-a:2'3'-c:3",2"- } \\
h: 2^{\prime \prime \prime}, 3^{\prime \prime}-\text {-j]phenazine }\end{array}$ \\
\hline UV & ultraviolet-visible \\
\hline
\end{tabular}

\section{Abbreviations}

A adenine 1, [2-(acridine-9-ylamino)ethyl] 2,6-bis[1-(3-morpholinopropyl)$1 H$-pyrazol-3-yl]pyridine 2,2'-bipyridine 4,4'-bipyridine cytosine 1,12-diazaperylene phenazine ransfer heteronuclear single quantum 4,4'-dimethyl-2,2'-bipyridine 4-(guanidylmethyl)-1,10-phenanthroline nuclear Overhauser effect roscopy 1,10-phenanthroline phenanthrenequinone diimine 2-phenylpyridine thymine tetrahydroanthracene $3,4,7,8$ tetramethylphenanthroline 5,10,15,20-tetrakis-(1-methyltetrapyrido[3,2-a:2'3'-c:3",2"ultraviolet-visible

Fig. 10. Three-way junction.

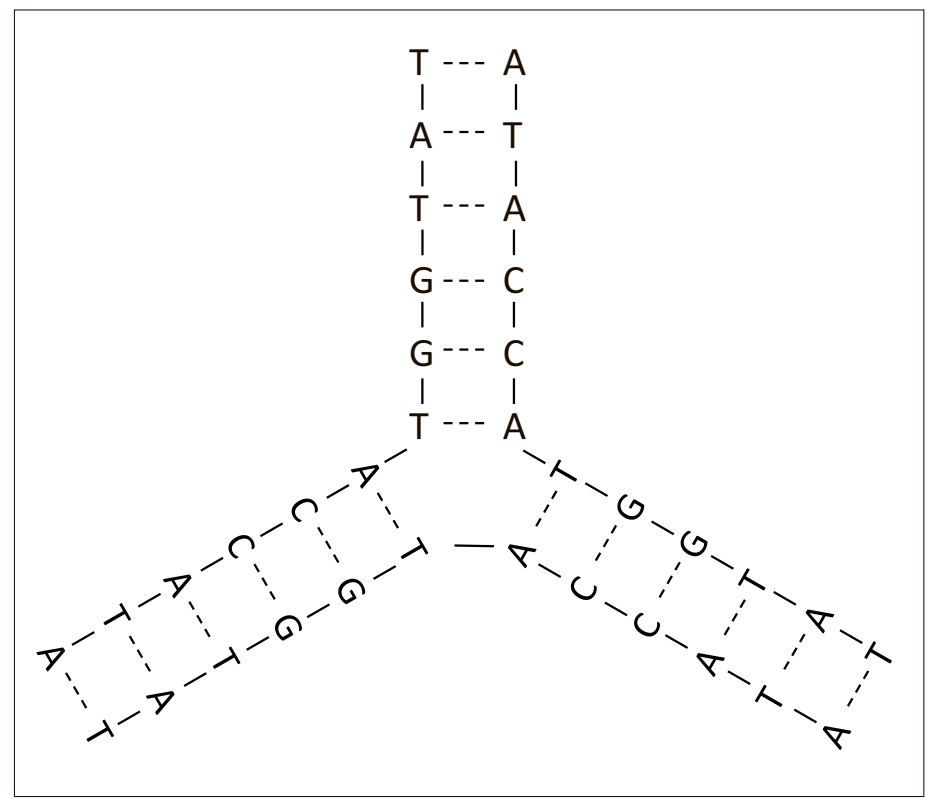

Received: December 21, 2016

[1] F. Mancin, P. Scrimin, P. Tecilla, Chem. Commun. 2012, 48, 5545 .

[2] D. Desbouis, I. P. Troitsky, M. J. Belousoff, L. Spiccia, B. Graham, Coord. Chem. Rev. 2012, $256,897$.

[3] A. Erxleben, 'Advances in the Development of DNA-Cleaving Metal Complexes as Anticancer Agents', in 'Elsevier Reference Module in Chemistry, Molecular Sciences and Chemical Engineering', Ed. J. Reedijk, Elsevier, Waltham, MA, 2015.

[4] R. A. Alderden, M. D. Hall, T. W. Hambley, J. Chem. Educ. 2006, 83, 728.

[5] R. Martinez, L. Chacon-Garcia, Curr. Med. Chem. 2005, 12, 127.

[6] R. R. Sinden, 'DNA structure and function', 1st ed., Academic Press, 1994, p. 398.

[7] D. Bikard, C. Loot, Z. Baharoglu, D. Mazel, Microbiol. Mol. Biol. Rev. 2010, 74, 570.

[8] R. M. Wadkins, Curr. Med. Chem. 2000, 7, 1. 
[9] V. R. Parvathy, S. R. Bhaumik, K. V. R. Chary, G. Govil, K. Liu, F. B. Howard, H. T. Miles, Nucleic Acids Res. 2002, 30, 1500.

[10] J. L. Huppert, Chem Soc. Rev. 2008, 37, 1375 and refs therein.

[11] J. L. Huppert, S. Balasubramanian, Nucleic Acids Res. 2005, 33, 2908.

[12] D. J. Patel, Nature 2002, 417, 807.

[13] G. N. Parkinson, M. P. Lee, S. Neidle, Nature 2002, 417, 876.

[14] A. Ambrus, D. Chen, J.-X. Dai, T. Bialis, R. A. Jones, D.-Z. Yang, Nucleic Acids Res. 2006, 34 , 2723.

[15] W. Li, P. Wu, T. Ohmichi, N. Sugimoto, FEBS Lett. 2002, 526, 77.

[16] L. S. Lerman, J. Mol. Biol. 1961, 3, 18.

[17] S. Neidle, Z. Abraham, CRC Crit. Rev. Biochem. 1984, 171, 73 .

[18] M. V. Keck, S. J. Lippard, J. Am. Chem. Soc. 1992, 114, 3386

[19] B. C. Jonathan, Biopolymers, 1997, 44, 201.

[20] H. Liu, P. J. Sadler, Acc Chem. Res. 2011, 44, 349 and refs therein.

[21] Y. J. Chu, S. Sorey, D. W. Hoffman, B. L. Iverson, J. Am. Chem. Soc. 2007, 129, 1304.

[22] Y. J. Chu, D. W. Hoffman, B. L. Iverson, J. Am. Chem. Soc. 2009, 131, 3499.

[23] J. X. Dai, C. Punchihewa, P. Mistry, A. T. Ooi, D. Z. Yang, J. Biol. Chem. 2004, 279, 46096.

[24] K. R. Barnes, S. J. Lippard, 'Cisplatin and Related Anticancer Drugs: Recent Advances and Insights', in 'Metal Complexes in Tumor Diagnosis and as Anticancer Agents', Eds. A. Sigel, H. Sigel, Met. Ions Biol. Syst. 2004, 42, 143.

[25] B. M. Zeglis, V. C. Pierre, J. K. Barton, Chem. Commun. 2007, 4565

[26] A. Sitlani, C. M. Dupureur, J. K. Barton, J. Am Chem. Soc. 1993, 115, 12589.

[27] J. K. Barton, L. A. Basile, A. T. Danishefsky, A. Alexandrescu, Proc. Nat. Acad. Sci. USA 1984, $81,1961$.

[28] S. J. Franklin, J. K. Barton, Biochemistry 1998 37, 16093

[29] A. Sitlani, E. C. Long, A. M. Pyle, J. K. Barton, J. Am. Chem. Soc. 1992, 114, 2303.

[30] A. M. Pyle, E. C. Long, J. K. Barton, J. Am. Chem. Soc. 1989, 111, 4520.

[31] R. H. Terbrueggen, J. K. Barton, Biochemistry, 1995, 34, 8227.

[32] H. K. Liu, F. Wang, J. A. Parkinson, J. Bella, P. J. Sadler, Chem. Eur. J. 2006, 12, 6151.

[33] H. K. Liu, S. J. Berners-Price, F. Wang, J. A Parkinson, J. Xu, J. Bella, P. J. Sadler, Angew. Chem. Int. Ed. 2006, 45, 8153.

[34] M. Kang, A. Chouai, H. T. Chifotides, K. R. Dunbar, Angew. Chem. Int. Ed. 2006, 45, 6148.

[35] H.-K. Liu, J. A. Parkinson, J. Bella, F. Wang, P. J. Sadler, Chem. Sci. 2010, 1, 258.

[36] M. Kloster, H. Kostrhunova, R. Zaludova, J. Malina, J. Kasparkova, V. Brabec, N. Farell, Biochemistry, 2004, 43, 7776.

[37] B. E. Bowler, K. J. Ahmed, W. I. Sunquist, L. S. Hollis, E. E. Whang, S. J. Lippard, J. Am. Chem. Soc. 1989, 111, 1299.

[38] M. D. Temple, W. D. McFaydyen, R. J. Holmes, W. A. Denny, V. Murray, Biochemistry, 2000 39, 5593.

[39] C. Oguey, N. Foloppe, B. Hartmann, PLoS One 2010, 5, e15931.

[40] S. Arnott, Nature 1986, 320, 313.

[41] M. J. Hannon, V. Moreno, M. J. Prieto, E. Moldrheim, E. Sletten, I. Meistermann, C. J. Isaac, K. J. Sanders, A. Rodger, Angew. Chem. Int. Ed. 2001, 40, 880.

[42] H. Y. Mei, J. K. Barton, Proc. Natl. Acad. Sci. USA 1988, 85, 1339

[43] S. Balasubramanian, S. Neidle, Curr. Opin. Chem. Biol. 2009, 13, 345.

[44] J. E. Reed, A. A. Amal, S. Neidle, R. Vilar, J. Am. Chem. Soc. 2006, 128, 5992
[45] R. Kieltyka, P. Englebienne, J. Fakhoury, C. Autexier, N. Moitessier, H. F. Sleiman, J. Am. Chem. Soc. 2008, 130, 10040.

[46] L. R. Keating, V. A. Szalai, Biochemistry 2004, 43, 15891.

[47] J.-T. Wang, X.-H. Zheng, Q. Xia, Z.-W. Mao, L.-N. Ji, K. Wang, Dalton Trans. 2010, 39, 7214

[48] G. J. Ryan, F. E. Poynton, R. B. P. Elmes, M. Erby, D. C. Williams, S. J. Quinn, T. Gunnlaugsson, Dalton Trans. 2015, 44, 16332.

[49] S. Banerjee, J. A. Kitchen, T. Gunnlaugsson, J. M. Kelly, Org. Biomol. Chem. 2013, 11, 5642 .

[50] S. Banerjee, J. A. Kitchen, T. Gunnlaugsson, J. M. Kelly, Org. Biomol. Chem. 2012, 10, 3033.

[51] S. Banerjee, S. A. Bright, J. A. Smith, J. Burgeat, M. Martinez-Calvo, D. C. Williams, J. M. Kelly, T. Gunnlaugsson, J. Org. Chem. 2014, 79, 9272 .

[52] A. Lauria, R. Bonsignore, A. Terenzi, A. Spinello, F. Giannici, A. Longo, A. M. Almerico, G. Barone, Dalton Trans. 2014, 43, 6108.

[53] A. Wolfe, G. H. Shimer, T. Meehan, Biochemistry 1987, 26, 6392.

[54] J. Sun, Y. An, L. Zhang, H.-Y. Chen, Y. Han, Y.J. Wang, Z.-W. Mao, L.-N. Ji, J. Inorg. Biochem. 2011, 105, 149 .

[55] L. Ren, A. Zhang, J. Huang, P. Wang, X. Weng, L. Zhang, F. Liang, Z. Tan, X. Zhou, ChemBioChem 2007, 8, 775.

[56] D.-L. Ma, C.-M. Che, S.-C. Yan, J. Am. Chem. Soc. 2009, 131, 1835 .

[57] S. Shi, X. Geng, J. Zhao, T. Yao, C. Wang, D. Yang, L. Zheng, L. Ji, Biochimie 2010, 92, 370.

[58] A. J. Bhattacharjee, K. Ahluwalia, S. Taylor, O. Jin, J. M. Nicoludis, R. Buscaglia, J. B. Chaires, D. J. P. Kornfilt, D. G. S. Marquardt, L. A. Yatsunyk, Biochimie 2011, 93, 1297.

[59] E. Dias, J. L. Battiste, J. R. Williamson, J. Am. Chem. Soc. 1994, 116, 4479.

[60] J.-L. Mergny, L. Lacroix, X. Han, J. L. Leroy, C. Helene, J. Am. Chem. Soc. 1995, 117, 8887.

[61] J.-L. Mergny, A.-T. Phan, L. Lacroix, FEBS Lett. 1998, 435, 74 .

[62] D. Suh, J. B. Chaires, Biorg. Med. Chem. 1995, 3, 723 .

[63] C. Hiort, P. Lincoln, B. Norden, J. Am. Chem. Soc. 1993, 115, 3448.

[64] J. F. Li, C. Dong, Spectrochim. Acta, Part A 2009, 71, 1938.

[65] M. S. Deshpande, A. A. Kumbhar, A. S. Kumbhar, M. Kumbhakar, H. Pal, U. B. Sonawane, R. R. Joshi, Bioconjugate Chem. 2009, $20,447$.

[66] L. Z. Zhang, G.-Q. Tang, J. Photochem. Photobiol. B 2004, 74, 119.

[67] C. Tong, Z. Hu, J. Wu, J. Fluoresc. 2010, 20, 261.

[68] S. J. Burya, D. A. Lutterman, C. Turro, Chem. Commun. 2011, 47, 1848.

[69] P. Wang, C.-H. Leung, D.-L. Ma, S.-C. Yan, C.M. Che, Chem. Eur. J. 2010, 16, 6900.

[70] T. Wilson, P. J. Costa, V. Felix, M. P. Williamson, J. A. Thomas, J. Med. Chem. 2013, 56, 8674.

[71] F. J. Meyer-Almes, D. Porschke, Biochemistry 1993, 32, 4246

[72] M. Lee, A. L. Rhodes, M. D. Wyatt, S. Forrow, J. Hartley, Biochemistry 1993, 32, 4237.

[73] M. McCann, J. McGinley, K. Ni, M. O’Connor, K. Kavanagh, V. McKee, J. Colleran, M. Devereux, N. Gathergood, N. Barron, A. Prisecaru, A. Kellett, Chem. Commun. 2103, 49, 2341.

[74] D. Monchaud, C. Allain, H. Bertrand, N. Smargiasso, F. Rosu, V. Gabelica, A. De Cian, J. L. Mergny, M. P. Teulade-Fichou, Biochimie 2008, 90, 1207

[75] E. Largy, F. Hamon, M. P. Teulade-Fichou, Anal. Bioanal. Chem. 2011, 400, 3419.
[76] P. L. T. Tran, E. Largy, F. Hamon, M. P. Teulade-Fichou, J. L. Mergny, Biochimie 2011, 93, 1288

[77] A. Dembska, B. Juskowiak, J. Fluoresc. 2010 20, 1029.

[78] J. R. Johansson, Y. Wang, M. P. Eng, N. Kann, P. Lincoln, J. Andersson, Chem. Eur. J. 2013 , 19,6246

[79] J. E. Reed, S. Neidle, R. Vilar, Chem. Commun. 2007, 4366.

[80] X.-H. Zheng, Y.-F. Zhong, C.-P. Tan, L.-N. Ji, Z.-W. Mao, Dalton Trans. 2012, 41, 11807.

[81] D. Sun, Y. Liu, D. Liu, R. Zhang, X. Yang, J. Liu, Chem. Eur. J. 2012, 18, 4285

[82] J.-L. Mergny, J.-C. Maurizot, ChemBioChem 2001, 2, 124

[83] A. Rodger, B. Norden, 'Circular Dichroism and Linear Dichroism', Oxford University Press, Oxford, 1997.

[84] S. Paramasivan, I. Rujan, P. H. Bolton, Methods 2007, 43, 324.

[85] J. R. Choudhury, R. Guddneppanavar, G Saluta, G. L. Kucera, U. Bierbach, J. Med. Chem. 2008, 51, 3069.

[86] N. Shahabadi, S. Kashanian, F. Darabi, DNA Cell Biol. 2009, 28, 589.

[87] N. Shahabadi, F. Darabi, M. Maghsudi, S. Kashanian, DNA Cell Biol. 2010, 29, 329.

[88] S. Masiero, R. Trotta, S. Pieraccini, S. De Tito, R. Perone, A. Randazzo, G. P. Spada, Org. Biomol. Chem. 2010, 8, 2683

[89] A. N. Lane, J. B. Chaires, R. D. Gray, J. O. Trent, Nucleic Acids Res. 2008, 36, 5482.

[90] V. Dapic, V. Abdomerovic, R. Marrington, J. Peberdy, A. Rodger, J. O. Trent, P. J. Bates, Nucleic Acids Res. 2003, 31, 2097.

[91] P. Balagurumoorthy, S. K. Brahmachari, $J$ Biol. Chem. 1994, 269, 21858.

[92] R. Giraldo, M. Suzuki, L. Chapman, D. Rhodes, Proc. Natl. Acad. Sci. USA 1994, 91, 7658 .

[93] C. Musetti, L. Lucatello, S. Bianco, A. P. Krapcho, S. A. Cadamuro, M. Palumbo, C. Sissi, Dalton Trans. 2009, 3657

[94] S. Bianco, C. Musetti, A. Waldeck, S Sparapani, J. D. Seitz, A. P. Krapcho, M Palumbo, C. Sissi, Dalton Trans. 2010, 39 , 5833.

[95] B. Fu, D. Zhang, X. Weng, M. Zhang, H. Ma Y. Ma, X. Zhou, Chem. Eur. J. 2008, 14, 9431.

[96] A. Rodger, Methods Enzymol. 1993, 226, 232.

[97] L. M. Wilhelmsson, E. K. Esbjorner, F. Westerlund, B. Norden, P. Lincoln, J. Phys. Chem. B 2003, 107, 11784.

[98] C. M. Dupureur, J. K. Barton, J. Am. Chem Soc. 1994, 116, 10286

[99] J. A. Smith, J. G. Collins, B. T. Patterson, F. R. Keene, Dalton Trans. 2004, 1277.

[100] A. Chouai, S. E. Wicke, C. Turro, J. Bacsa, K R. Dunbar, D. Wang, R. P. Thummel, Inorg. Chem. 2005, 44, 5996.

[101] J. R. Choudhury, U. Bierbach, Nucleic Acids Res. 2005, 33, 17.

[102] J. C. Peberdy, J. Malina, S. Khalid, M. J. Hannon, A. Rodger, J. Inorg. Biochem. 2007, 101, 1937.

[103] A. Terenzi, C. Ducani, V. Blanco, L. Zerzankova, A. F. Westendorf, C. Peinador, J. M. Quintela, P. J. Bednarski, G. Barone, M. J. Hannon, Chem. Eur. J. 2012, 18, 10983.

[104] J. A. R. Navarro, E. Barea, M. A. Galindo, J. M. Salas, M. A. Romero, M. Quiros, N. Masciocchi, S. Galli, A. Sironi, B. Lippert, J. Solid State Chem. 2005, 178, 2436 and refs. therein.

[105] M. A. Galindo, D. Olea, M. A. Romero, J. Gomez, P. del Castillo, M. J. Hannon, A Rodger, F. Zamora, J. A. R. Navarro, Chem Eur. J. 2007, 13, 5075.

[106] L. Cerasino, M. J. Hannon, E. Sletten, Inorg Chem. 2007, 46, 6245. 